\title{
The Effects of Per Capita Tribal Payments on the Fertility, Education, and Labor Force Participation of Tribal Members
}

\author{
James Richard Hill (Corresponding author) \\ Department of Economics, 317 Sloan Hall \\ Central Michigan University, Mt. Pleasant, MI 48859 \\ Tel: 1-989-774-3706_E-mail: hill1jr@cmich.edu
}

Peter A. Groothuis

Department of Economics, 3093 Raley Hall

Appalachian State University, Boone, NC 28608

Tel: 1-828-262-6077Ｅ-mail: groothuispa@appstate.edu

Received: September 17, 2012 Accepted: September 30, 2012

doi:10.5296/ber.v2i2.2401 URL: http://dx.doi.org/10.5296/ber.v2i2.2401

\begin{abstract}
The purpose of this research is to provide a preliminary examination of the effects of per capita tribal payments on the decision making of tribal members. Standard microeconomic theory suggests that unearned income changes the labor-leisure tradeoff in utility maximization models. While the results of per capita payments on hours of work can be easily anticipated, the effects of these payments on human capital accumulation and family size are more ambiguous. Using Census data from 1990 and 2000 we shed some light on the impact of these per capita tribal payments on the lives of the recipients. We concentrate on three tribes in the state of Michigan: the Saginaw Chippewa Tribe, the Keweenaw Bay Indian Community, and the Pokagon Band of Potawatomi Indians of Michigan. The results lend support to the basic labor theory conclusion that an increase in nonlabor income causes individuals to decrease their work efforts. There is also weak evidence that the payment of per capita payments from casino profits is increasing the fertility rate of Saginaw Chippewa tribal families.
\end{abstract}

Keywords: Indian casino, Per capita payments, Labor-leisure tradeoff, Fertility 


\section{Introduction}

From its modest beginnings in bingo halls among the Seminole tribe in Florida gambling on Indian Reservations has exploded into a several billion dollar industry. The nature of this gambling has changed shape until it now appears indistinct from that found in the casinos of Atlantic City or Las Vegas in many cases. These changes were aided by the Supreme Court ruling in February, 1988, that barred states from enforcing their civil codes on Indian reservations (State of California v. Cabazon Band of Mission Indians). Therefore if a state allowed some form of gambling, even if only for charitable or church-related fundraising, then the state could not prohibit such activity on reservations. In an effort to clarify and codify the rights of Tribes to open casinos and bingo halls and the rights of the federal government and state governments to regulate this activity Congress passed the Indian Gaming Regulatory Act of 1988 (Evans and Topoleski 2002). The National Indian Gaming Commission (NIGC) was established and given oversight authority of both Class II activity (bingo and similar games) and Class III activity (slot machines and casino games).

In order to conduct Class III gaming on a reservation the Tribal Authorities must have an approved compact with the state government in which the reservation is located. The NIGC approves such compacts and has authority to oversee the negotiation process for these compact should there be an impasse. For instance, the state of Michigan has 11 State-Tribal compacts that allow the operation of 18 casinos. The Michigan Gaming Control Board (MGCB) inspects tribal casinos and documents to assure compliance with the compacts. The MGCB also audits the financial records of the tribes operations to ensure that $8 \%$ of Net Win proceeds from electronic games of chance are going to the state of Michigan and semi-annual $2 \%$ payments are going to local municipalities

According to Barlett and Steele (2002) in 2001 "290 Indian casinos in 28 states pulled in at least $\$ 12.7$ billion in revenue." But a minority of these casinos accounts for the bulk of the revenue; 39 casinos in 2001 generated $\$ 8.4$ billion (Barlett and Steele, 2002). According to the Indian Gaming Regulatory Act:

"net revenues from any tribal gaming are not to be used for purposes other than-

(i) to fund tribal government operations and programs;

(ii) to provide for the general welfare of the Indian tribe and its members;

(iii) to promote tribal economic development;

(iv) to donate to charitable organizations; or

(v) to help fund operations of local government agencies;".

While tribes have used the casino revenues in various ways to improve the lives of their members they have also been castigated for expending millions of dollars to hire political consultants to lobby Congress in the past to extend or preserve their gaming rights (Barlett and Steele, 2002).

Of the roughly 200 tribes that operate casinos, some operate more than one, only 73 tribes as 
of June 2003 had allocation plans to distribute shares of casino profits to tribal members (indianz.com). Most so-called per capita payments are modest in size, less than $\$ 10,000$ annually, but the Cabazon Band of Mission Indians in California reportedly reduced the per cap payments to $\$ 14,000$ a month.

The purpose of this research is to provide a preliminary examination of the effects of per capita tribal payments on the decision making of tribal members. Standard microeconomic theory suggests that unearned income changes the labor-leisure tradeoff in utility maximization models. Therefore, the first research question is: 1.) Have per capita payments caused a decline in hours of work among recipients? The effects of these payments on human capital accumulation and family size are more ambiguous. Using Census data from 1990 and 2000 we hope to shed some light on the impact of these per capita tribal payments on the lives of the recipients. Therefore, the other research questions to be answered are: 2.) Have per capita tribal payments caused a decline in educational attainment by recipients? 3.) Have per capita payments caused an increase in fertility among recipients?

We shall concentrate on three tribes in the state of Michigan: the Saginaw Chippewa Tribe, the Keweenaw Bay Indian Community, and the Pokagon Band of Potawatomi Indians of Michigan. The first two tribes signed compacts with the state of Michigan in 1993 and opened full-scale gaming casinos thereafter; the Pokagon Band signed a compact in 1998 but just opened their casino in 2007.

The Saginaw Chippewa Tribe has generated substantial revenue from their casino, The Soaring Eagle; the casino is located in Mt. Pleasant, Michigan near to the geographic center of the Lower Peninsula. The reservation is not far from the town of Midland, Michigan world headquarters for Dow Corporation; the cities of Saginaw and Bay City, Michigan are also within easy driving range and the casino is located just off U.S. 27 a major artery through the heart of Michigan connecting Lansing to the cottages and lakes up north. The Tribe initiated a per capita member payment in the mid-1990s which is currently at $\$ 72,000$ annually for adults and $\$ 12,000$ annually per child. These payments grew over time since their inception and peaked about four years ago. The tribe paid supplemental bonuses to tribe members based on the casino profits for a few years until about four years ago when revenue leveled off. The opening of casinos in the Detroit areas as well as more Native American casinos around the state has created more competition for the Soaring Eagle; the opening of the Detroit casinos has allowed this tribe to cease payment of their $8 \%$ payments to the state.

The Keweenaw Bay Indian Community operates two casinos: the Ojibwa Casino Resort in Baraga, Michigan in a remote area of the Upper Peninsula and the Ojibwa II near the city of Marquette in the Upper Peninsula. Neither of these casinos generates as much revenue as the Soaring Eagle Casino. Table 1 illustrates the difference in gaming between these two tribes. The Keweenaw Bay Indian Community currently has 684 slot machines in its two casinos combined compared to 4347 slot machines in the Soaring Eagle Casino of the Saginaw Chippewa Indian Tribe. For the October 1, 2006 to September 30, 2007 time period the Keweenaw Bay Indian Community paid $\$ 665,649.35$ in $2 \%$ money to the local community whereas the Saginaw Chippewa Tribe paid $\$ 7,329,997.95$ for the same period. The 


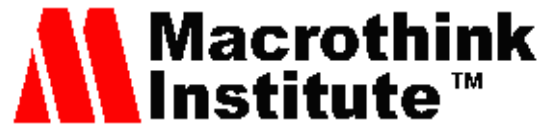

Business and Economic Research ISSN 2162-4860 2012, Vol. 2, No. 2

Keweenaw Bay Indian Community does not provide per capita payments to members. Revenues from the tribe's two casinos are used according to their website: "supporting government programs of the Keweenaw Bay Indian Community such as health, housing, and social service programs to assist the membership of the Community."

The Pokagon Band of Potawatomi Indians encompasses a ten county region, six in northern Indiana and four in the southwestern corner of Michigan. The new casino for the Michigan tribe is located in New Buffalo, Michigan. As shown in Table 1 it has 3000 slot machines; no figures on $2 \%$ or $8 \%$ money are available since the casino just opened. The location of this tribe is not as remote as the Keweenaw Bay Indian Community. It is not far from Kalamazoo and Benton Harbor, Michigan and Michigan City and South Bend, Indiana.

Table 1. Comparison of Saginaw Chippewa Indian Tribe Gaming vs. Keweenaw Bay Indian Community Gaming

\begin{tabular}{|c|c|c|c|c|}
\hline & \multicolumn{2}{|l|}{ Saginaw Chippewa Indian Tribe } & \multicolumn{2}{l|}{ Keweenaw Bay Indian Community } \\
\hline Year & $2 \%$ Money & $8 \%$ Money & $2 \%$ Money & $8 \%$ Money \\
\hline 1994 & $1,696,115.42$ & $6,784,461.79$ & $206,000.84$ & $719,417.33$ \\
\hline 1995 & $3,388,867.25$ & $13,555,505.22$ & $360,407.23$ & $1,423,156.83$ \\
\hline 1996 & $4,177,889.84$ & $16,740,180.72$ & $391,578.76$ & $1,681,683.26$ \\
\hline 1997 & $5,493,601, .88$ & $21,974,407.55$ & $510,128.96$ & $1,858,024.68$ \\
\hline 1998 & $6,659,671.60$ & $26,638,686.37$ & $467,177.72$ & $1,983,756.58$ \\
\hline 1999 & $7,362,007.50$ & $10,202,077.74$ & $503,556.85$ & $2,089,362.58$ \\
\hline 2000 & $7,353,826.54$ & & $555,265.08$ & $2,221,060.40$ \\
\hline 2001 & $7,150,869.42$ & & $583,549.00$ & $2,236,740.08$ \\
\hline 2002 & $7,683,494.32$ & & $594,197.62$ & $2,476,915.32$ \\
\hline 2003 & $7,716,454.60$ & & $624,866.42$ & $2,496,796.59$ \\
\hline 2004 & $7,726,614.44$ & & $627,799.76$ & $2,511,199.04$ \\
\hline 2005 & $7,732,270.94$ & & $673,471.56$ & $1,970,641.87$ \\
\hline 2006 & $7,899,977.49$ & & $591,596.72$ & $2,451,932.11$ \\
\hline 2007 & $7,329,977.95$ & & $665,649.35$ & $2,554,121.14$ \\
\hline Totals & $89,371,668.19$ & $95,895,249.39$ & $7,355,245.87$ & $28,674,807.83$ \\
\hline Number of & Soaring Eagle & & Casino: 355 & Marquette Ojibwa II \\
\hline slots in & Casino: 4347 & & & Casino: 329 \\
\hline 2007 & & & & \\
\hline
\end{tabular}

The data in this table was taken from a website for the Michigan Gaming Control Board: http://www.michigan.gov/mgcb

The Saginaw Chippewa Tribe is the main focus of this study because of the generous per capita payment received by tribal members. Comparison to statistics from the other two tribes will provide some basis upon which to judge the effects of the per capita payments on tribe members' decision-making. The Keweenaw Bay Indian Community has had a casino in operation for as long as Saginaw Chippewa Tribe but does not pay a per capita payment to members. The Pokagon Band of Potawatomi Indians has not had gambling over the time 
period under study and has a similar location to the Saginaw tribe in terms of non-casino employment opportunities.

\section{Literature Review}

The proliferation of Native American Casinos in recent years has led to a surge of economic research on a variety of issues related to their presence. Research on the empirical relationship between crime and gambling has been resurrected. The relationship between the spread of casino gambling and bankruptcy has been studied. The possibility that state revenue and/or state lottery money will decline as a result of increased Indian gaming opportunities has drawn careful scrutiny. The ability of Native casinos to stimulate regional economic development has been analyzed.

The correlation between gambling and crime is not a new topic but the containment of gambling to the state of Nevada and Atlantic City, New Jersey made research on this issue unappealing as a topic of national interest. With the spread of gambling at Indian Casinos throughout twenty eight states the public in general and community leaders in particular want to know the extent to which these casinos may increase crime near their locations. Grinols and Mustard (2006) conclude that the effect on crime of a casino is low directly after the opening but grows over the years. Overall their research suggests that approximately $8 \%$ of the crime in counties with a casino were attributable to the casino. Gazel, Rickman, and Thompson (2001) found that the presence of a casino not only increased that county's crime rates but also raised crime rates in adjacent counties as well.

Conclusions on the effect of the spread of casinos on bankruptcy rates are somewhat mixed. Garrett and Nichols (2005) find that residents in southern states who visit out-of-state casinos have higher bankruptcies filings. However, their research focuses on destination resort casinos, not the typical Native American casino. Barron, Staten, and Wilshusen (2002) find that the proximity of a casino increases local bankruptcy rates fairly significantly but the effect on national bankruptcy filings is less pronounced. Boardman and Perry (2007) and De la Vina and Bernstein (2002) find no impact on county bankruptcy rates from the introduction of casino gambling.

Several studies have analyzed the extent to which casino gambling has lowered states' revenues from lotteries. Elliott and Navin (2002) and Fink and Rork (2003) provide estimates of the substitutability between commercial gambling and state lotteries. While commercial gambling and state lotteries may cannibalize each other as a state revenue source and give policy makers choice concerns, the growth of Native American casinos adds another dimension to the debate. Siegel and Anders (2001) confirm that a substitution effect is present in Arizona between the increase in slot machines at Indian casinos and state lottery revenue, particularly from the Lotto. Depending on the nature of a state's tribal compacts the lost revenue from the lotteries may not be totally replaced by whatever payments are made by the tribes for their gaming rights. In addition, in the early compacts signed by the state of Michigan with the tribes, the tribal leaders themselves were given the right to distribute the $2 \%$ money paid from net slot machine revenue to local government agencies usurping local leaders' authority in this capacity. Anders, Siegel, and Yacoub (1998) have also used data 
from the state of Arizona to suggest that the rise in Gaming revenue from Indian casinos is robbing other businesses of revenue that pay state taxes.

The most important research on the growth of Indian Gaming from the perspective of this article involves the economic development aspects of these casinos. Taylor and Kalt (2005) used 1990 and 2000 U.S. Census data on Native Americans to analyze changes in fifteen measures of well-being. They contrast results for gaming versus non-gaming areas. Improvements in these measures were greater for Native Americans than the U.S. population as a whole but conditions for Indian Tribal members are still below the averages for the general population. Improvements in the measures selected were generally greater in gaming versus non-gaming Native American areas. Using county level data Evans and Topoleski (2002) look at differences in economic measures before and after tribes opened casinos throughout the U.S. between 1983 and 1999. They conclude that in counties where an Indian casino opened there was about a five percent increase in jobs per adult above the median value. Most growth in employment however was among non-Native Americans. Using Granger-causality analysis and state level data from 1991 to 2005 Walker and Jackson (2007) conclude that casino gambling in general does not have an impact on economic growth. These results contradict the authors own previous findings (Walker and Jackson (1998)) based on quarterly data using the same causality technique. Using restricted-use data from the 1900 and 200 Census long-form, Evans and Kim (2005) conclude that the opening of an Indian casino increased employment and wages of low-skilled workers. Unfortunately high school attendance, high school graduation and college enrollment fell among young Native Americans on reservations following the opening of a casino compared to reservations with no gambling.

The results of this last study are of particular interest to the focus of this paper. Our research effort intends to extend the localized approach of Evans and Kim (2005) one step further. While the opening of a casino on a reservation may spur Native American youth to drop out of school and enter the labor force, what happens if the casino is so profitable that substantial per capita payments are made to tribal members? Standard Microeconomic analysis suggests that such a pure income effect should cause individuals to work less. Would such payments exacerbate the lower educational investment results found by Evans and Kim (2005) or reverse these findings? Lastly, what effect does per capita payments to parents for children who are enrolled as tribal members have on fertility rates?

\section{Data and Methodology}

Ideally we would like to have a panel data set to study the effects of the per capita payments on individuals over time. Such a data set does not exist. Leaders of the Saginaw Chippewa Indian Tribe do not release any information on the per capita payments to the media or public and have not answered any of our requests for information. The best available source of information is census data. Using 1990 and 2000 census data on the "Characteristics of American Indians by Tribe and Language" we will try to piece together a picture of the effects of the per capita payments on the Saginaw Chippewa tribal members. With incomplete data and no ability to match up individuals between census years we will have to rely on 
average figures and changes between census years to infer patterns of behavior. This approach is a poor substitute for regression analysis but may provide a stimulus for discussion and further exploration of the socio-economic impacts of per capita payments.

Various characteristics of the Saginaw Chippewa Tribe, the Keweenaw Bay Indian Community, and the Pokagon Band of Potawatomi Indians will be presented in the tables in this section. As stated above the data has been extracted from 1990 and 2000 census publications. Unfortunately there are no 1990 figures available for the Pokagon Band of Potawatomi Indians because this group was not a federally recognized tribe at the time of the 1990 census. The data collected may vary from the 1990 to the 2000 census making it difficult to compare the same statistics.

Table 2. 1990 and 2000 Income and Earnings Data

\begin{tabular}{|c|c|c|c|c|c|c|c|c|}
\hline & \multicolumn{2}{|c|}{$\begin{array}{c}\text { Saginaw Chippewa } \\
\text { Tribe }\end{array}$} & \multicolumn{2}{c|}{$\begin{array}{c}\text { Keweenaw Bay Indian } \\
\text { Community }\end{array}$} & \multicolumn{2}{c|}{$\begin{array}{c}\text { Pokagon Band of } \\
\text { Potawatomi }\end{array}$} & \multicolumn{2}{c|}{$\begin{array}{c}\text { American Indian and } \\
\text { Alaska Native }\end{array}$} \\
\hline Data & $1990^{*}$ & $2000^{* *}$ & 1990 & 2000 & 1990 & 2000 & $1990^{*}$ & $2000^{*}$ \\
\hline $\begin{array}{c}\text { Median household } \\
\text { income in previous year }\end{array}$ & $\$ 26,518$ & $\$ 49,489$ & $\$ 22,885$ & $\$ 31,791$ & NA & $\$ 34,750$ & $\$ 19,900$ & $\$ 30,599$ \\
\hline $\begin{array}{c}\text { Median family income in } \\
\text { previous year }\end{array}$ & $\$ 27,273$ & $\$ 48,750$ & $\$ 24,327$ & $\$ 46,528$ & NA & $\$ 36,023$ & $\$ 21,619$ & $\$ 33,144$ \\
\hline $\begin{array}{c}\text { Mean household income } \\
\text { in previous year }\end{array}$ & $\$ 27,424$ & NA & $\$ 26,112$ & NA & NA & NA & $\$ 26,012$ & NA \\
\hline $\begin{array}{c}\text { Mean family income in } \\
\text { previous year }\end{array}$ & $\$ 26,901$ & NA & $\$ 28,228$ & NA & NA & NA & $\$ 27,796$ & NA \\
\hline $\begin{array}{c}\text { Per Capita Income in } \\
\text { previous year }\end{array}$ & $\$ 7,776$ & $\$ 29,397$ & $\$ 8,256$ & $\$ 15,247$ & NA & $\$ 10,832$ & $\$ 8,284$ & $\$ 12,893$ \\
\hline $\begin{array}{c}\text { Mean earnings of } \\
\text { households with earnings } \\
\text { in previous year }\end{array}$ & $\$ 29,594$ & NA & $\$ 25,231$ & NA & NA & Na & $\$ 27,184$ & NA \\
\hline $\begin{array}{c}\text { Worker mean earnings in } \\
\text { the previous year }\end{array}$ & NA & $\$ 34,148$ & NA & $\$ 28,570$ & NA & $\$ 31,468$ & NA & $\$ 26,285$ \\
\hline
\end{tabular}

*Data for the 1990 figures in this table were derived from Table 6: Income and Poverty Status in 1989 of American Indian Tribes: 1990 from Characteristics of American Indians by Tribe and Language: 1990 Census of Population. Source: U.S. Census Bureau, Population Division, Racial Statistics Branch: 1990 (CP-3-7).

**Data for the 2000 figures in this table were derived from Table 10 Work Status and Income in 1999 for Selected American Indian and Alaska Native Tribes (One Tribe Reported): 2000 and Table 11 Earnings in 1999 of Full-Time, Year-Round Workers, by Sex for Selected American Indian and Alaska Native Tribes (One Tribe Reported): 2000 from Characteristics of American Indians and Alaska Natives by Tribe and Language: 2000 Census of Population and Housing. Source: U.S. Census Bureau, Population Division, 2000 (PHC-5).

Both the Saginaw Chippewa Tribe and the Keweenaw Bay Indian Community saw substantial increases in median income figures, shown in Table 2, between 1990 and 2000. These increases were bigger than the increase for the American Indian and Alaska Native community at large. The employment opportunities resulting from the opening of the casinos for these tribes are probably responsible for these income improvements to some 


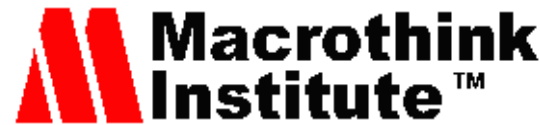

Business and Economic Research

ISSN 2162-4860

2012, Vol. 2, No. 2

extent. The substantial rise in the per capita income levels for the Saginaw Chippewa Tribe $(\$ 7,776$ to $\$ 29,397)$ compared to that of the Keweenaw Bay group $(\$ 8,256$ to $\$ 15,247)$ suggests that there are other factors at work. The per capita payments made to Saginaw tribal members from the casino profits have obviously boosted these figures well beyond the advances achieved by wages alone.

Figures in Table 3 show the overall population of American Indians and Alaska Native Tribes grew from 1,937,391 in 1990 to 2,447,989 in 2000, a 26.3\% increase, while the Saginaw Chippewa Tribe saw a $177.6 \%$ increase in population and the Keweenaw Bay Indian Community had a $84.7 \%$ increase. The reported growth in population for both of these Michigan tribes is certainly not a function simply of increased fertility rates and/or decreased morbidity rates. It must be noted that more and more people are claiming Native American heritage to particular tribes to gain benefits from casino profits. While the Keweenaw Bay Indian Community does not make per capita payments it does offer certain benefits to members in the area of health, housing, and social services. Enrollment in the Saginaw Chippewa Tribe swelled following the start of per capita payments. Eventually the tribe froze the rolls and would only accept petitions during certain time periods. Anyone claiming membership in the tribe must first apply to the Enrollment Office or Tribal Certifier. If denied at this stage the claimant can appeal to the Office of Administrative Hearings. During this hearing a claimant can be represented by tribal approved counsel. If denied membership after the hearing another appeal can be brought before the Tribal Court and the Tribal Appeals Court. Some lawyers in the state now specialize in tribal enrollment cases and charge a percentage of the per capita payments as their fee if successful. It would appear that the enormous growth between the 1990 and 2000 census for those claiming to be Saginaw Chippewa Indians has been fueled by the per capita payments.

Table 3. Selected 1990 and 2000 Population Characteristics

\begin{tabular}{|c|c|c|c|c|c|c|c|c|}
\hline \multirow[b]{2}{*}{ Characteristic } & \multicolumn{2}{|c|}{$\begin{array}{c}\text { Saginaw } \\
\text { Chippewa Tribe }\end{array}$} & \multicolumn{2}{|c|}{$\begin{array}{l}\text { Keweenaw Bay } \\
\text { Indian Community }\end{array}$} & \multicolumn{2}{|c|}{$\begin{array}{l}\text { Pokagon Band } \\
\text { of Potawatomi }\end{array}$} & \multicolumn{2}{|c|}{$\begin{array}{l}\text { American Indian and } \\
\text { Alaska Native }\end{array}$} \\
\hline & $1990^{*}$ & $2000 * *$ & 1990 & 2000 & 1990 & 2000 & $1990^{*}$ & $2000^{*}$ \\
\hline Total Population & 847 & 2351 & 699 & 1291 & NA & 872 & $1,937,391$ & $2,447,989$ \\
\hline Median Age & 23.9 & 29.1 & 25.9 & 31.8 & NA & 19.9 & 27.0 & 28.5 \\
\hline Number of Children under 5 & 87 & 232 & 53 & 44 & NA & 72 & 187,833 & 204,645 \\
\hline$\%$ of Total Population under 5 & $10.3 \%$ & $9.9 \%$ & $7.6 \%$ & $3.4 \%$ & NA & $8.3 \%$ & $9.7 \%$ & $8.4 \%$ \\
\hline 18 yrs. and older & 507 & 1625 & 460 & 922 & NA & 486 & $1,275,566$ & $1,633,699$ \\
\hline $\begin{array}{l}18 \text { yrs. and older as \% of } \\
\text { Total Population }\end{array}$ & $59.8 \%$ & $69.1 \%$ & $65.8 \%$ & $71.4 \%$ & NA & $55.7 \%$ & $65.8 \%$ & $66.7 \%$ \\
\hline 65 yrs. and older & 34 & 132 & 32 & 47 & NA & - & 93,141 & 137,586 \\
\hline $\begin{array}{l}65 \text { yrs. and older as \% of } \\
\text { Total Population }\end{array}$ & $4.0 \%$ & $5.6 \%$ & $4.6 \%$ & $3.6 \%$ & NA & - & $4.8 \%$ & $5.6 \%$ \\
\hline Average Household Size & 3.32 & 2.98 & 3.03 & 2.62 & NA & 3.41 & 3.03 & 3.06 \\
\hline Average Family Size & NA & 3.34 & NA & 3.36 & NA & 3.67 & NA & 3.55 \\
\hline Total Family Households & 224 & 640 & 177 & 287 & NA & 189 & 449,281 & 563,651 \\
\hline $\begin{array}{l}\text { Percent of Total Family } \\
\text { Households with Female } \\
\text { head, no husband present, and } \\
\text { children under } 18 \text { yrs old }\end{array}$ & $26.8 \%$ & $26.3 \%$ & $26 \%$ & $21.6 \%$ & NA & $16.4 \%$ & $17.4 \%$ & $18.1 \%$ \\
\hline
\end{tabular}




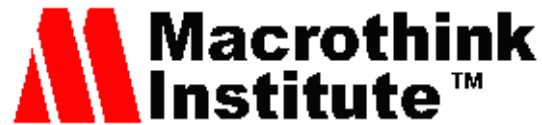

Business and Economic Research ISSN 2162-4860 2012, Vol. 2, No. 2

*Data for the 1990 figures in this table were derived from Table 1: American Indian Population by Selected Tribes: 1990, and Table 2: General, Family, and Household Characteristics of American Indian Tribes: 1990, from Characteristics of American Indians by Tribe and Language: 1990 Census of Population. Source: U.S. Census Bureau, Population Division, Racial Statistics Branch: 1990 (CP-3-7).

**Data for the 2000 figures in this table were derived from Table 3 Age and Sex for Selected American Indian and Alaska Native Tribes (One Tribe Reported): 2000 and Table 4 Households and Families With an American Indian and Alaska Householder for Selected American Indian and Alaska Native Tribes (One Tribe Reported): 2000, from Characteristics of American Indians and Alaska Natives by Tribe and Language: 2000 Census of Population and Housing. Source: U.S. Census Bureau, Population Division, 2000 (PHC-5).

The change in the distribution of population by age for the Saginaw Chippewa Tribe and the Keweenaw Bay Indian Community also show the effects of enrollment issues. The median age for the Saginaw Tribe rose from 23.9 years to 29.1 years between 1990 and 2000; the median age rose from 25.9 to 31.8 years for the Keweenaw Bay group. This is a dramatic increase compared to the overall change from 27 to 28.5 years for all American Indians and Alaska Natives combined. Despite the aging of the Saginaw tribe the percentage of the tribe under 5 years of age remained fairly steady, $10.3 \%$ to $9.9 \%$, and much higher than the figures for the Keweenaw Bay Indian Community, $7.6 \%$ to 3.4\%. The number of children under five is higher in 2000 for the Saginaw Tribe compared to the Pokagon Band of Potawatomi, 8.3\%, and for the American Indian and Alaska Native overall group, 8.4\%. Perhaps the per capita payment for children in the Saginaw Chippewa Tribe, reportedly $\$ 12,000$ annually, has provided an incentive to have children. However, the average household size has declined from 1990 to 2000 for the Saginaw Tribe, 3.32 to 2.98, similar to the trend for the Keweenaw Bay Indian Community, 3.03 to 2.62. The average household size for American Indians and Alaska Natives held steady, 3.03 to 3.06; the 2000 figure for the Pokagon Band is quite high by comparison, 3.41. Average family size for the Saginaw Tribe is comparable to that of the Keweenaw Bay group but somewhat lower than the Pokagon Band and the overall American Indian and Alaska Native figures. Figures for the percent of total family households with female head, no husband present, and children under 18 years old are higher for the Saginaw Chippewa tribe than the other groups reported but there is no significant change between 1990 and 2000; it does not appear that the per capita payments for children have led to any increase in these already inflated percentages.

Table 4. 1990 and 2000 Educational and Labor Force Characteristics

\begin{tabular}{|c|c|c|c|c|c|c|c|c|}
\hline & \multicolumn{2}{|c|}{$\begin{array}{c}\text { Saginaw } \\
\text { Chippewa Tribe }\end{array}$} & \multicolumn{2}{c|}{$\begin{array}{c}\text { Keweenaw Bay } \\
\text { Indian Community }\end{array}$} & \multicolumn{2}{c|}{$\begin{array}{c}\text { Pokagon Band of } \\
\text { Potawatomi }\end{array}$} & \multicolumn{2}{c|}{$\begin{array}{c}\text { American Indian } \\
\text { And Alaska Native }\end{array}$} \\
\hline Characteristic & $1990^{*}$ & $2000^{* *}$ & 1990 & 2000 & 1990 & 2000 & $1990^{*}$ & $2000^{*}$ \\
\hline $\begin{array}{c}\text { Population 16 -19 yrs. not } \\
\text { enrolled in school and not } \\
\text { high school grad. }\end{array}$ & $9 \%$ & $20.2 \%$ & $2.2 \%$ & $3.8 \%$ & NA & $32.1 \%$ & $18.2 \%$ & $16.1 \%$ \\
\hline $\begin{array}{c}25 \text { yrs. and older high school } \\
\text { grad. or higher }\end{array}$ & $68.1 \%$ & $76.5 \%$ & $75.9 \%$ & $85.6 \%$ & NA & $84.6 \%$ & $65.6 \%$ & $70.9 \%$ \\
\hline
\end{tabular}




\section{Mll Macrothink}

Business and Economic Research ISSN 2162-4860 2012, Vol. 2, No. 2

\begin{tabular}{|c|c|c|c|c|c|c|c|c|}
\hline $\begin{array}{c}25 \text { yrs. and older Bach. } \\
\text { degree or higher }\end{array}$ & $8.9 \%$ & $6.5 \%$ & $5.5 \%$ & $13.8 \%$ & $\mathrm{NA}$ & $7.4 \%$ & $9.4 \%$ & $11.5 \%$ \\
\hline $\begin{array}{c}\text { Percentage of population 16 } \\
\text { yrs. and older in labor force }\end{array}$ & $\mathrm{NA}$ & 57.2 & $\mathrm{NA}$ & $68 \%$ & $\mathrm{NA}$ & $67.4 \%$ & $\mathrm{NA}$ & $61.1 \%$ \\
\hline $\begin{array}{c}\text { Percentage of population 16 } \\
\text { and over who worked at all } \\
\text { in previous year }\end{array}$ & $68.3 \%$ & $65.8 \%$ & $80.3 \%$ & $79 \%$ & $\mathrm{NA}$ & $79.7 \%$ & $67.3 \%$ & $67.5 \%$ \\
\hline $\begin{array}{c}\text { Percentage of population 16 } \\
\text { and over who worked 40 or } \\
\text { more weeks in previous year }\end{array}$ & $45.8 \%$ & $47.8 \%$ & $37.1 \%$ & $55 \%$ & $\mathrm{NA}$ & $52.5 \%$ & $37.4 \%$ & $47 \%$ \\
\hline
\end{tabular}

*Data for the 1990 figures in this table were derived from Table 4: Educational and Labor Force Characteristics of American Indian Tribes: 1990 and Table 5: Industry, Occupation, and Work Status in 1989 of American Indian Tribes: 1990, from Characteristics of American Indians by Tribe and Language: 1990 Census of Population. Source: U.S. Census Bureau, Population Division, Racial Statistics Branch: 1990 (CP-3-7).

**Data for the 2000 figures in this table were derived from Table 7 Education and Veteran Status for Selected American Indian and Alaska Native Tribes (One Tribe Reported): 2000, Table 9 Employment Status and Journey to Work for Selected American Indian and Alaska Native Tribes (One Tribe Reported): 2000, and Table 10 Work Status and Income in 1999 for Selected American Indian and Alaska Native Tribes: 2000 from Characteristics of American Indians and Alaska Natives by Tribe and Language: 2000 Census of Population and Housing. Source: U.S. Census Bureau, Population Division, 2000 (PHC-5).

Data in Table 4 on educational attainment show a disturbing increase in the percentage of

the 16 to 19 year old population for the Saginaw Chippewa Tribe that is not enrolled in school and is not a high school graduate, $9 \%$ in 1990 to $20.2 \%$ in 2000 . There was a slight increase for the Keweenaw Bay Indian Community from 2.2\% to 3.8\%; there was a slight decline in this percentage for the overall American Indian and Alaska Native group from $18.2 \%$ to $16.1 \%$. The figure for the Pokagon Band of Potawatomi was a startling $32.1 \%$ in 2000. The percentage of the population 25 years and older with a high school degree or higher has risen substantially for the Saginaw Tribe from 1990 to 2000 and is higher than the percentages for the American Indian and Alaska Native overall population but still lag behind the figures for the Keweenaw Bay group and Pokagon Band. The percentage of the population 25 years and older with a bachelor degree or higher has fallen somewhat for the Saginaw Tribe from 1990 to 2000 and risen for the Keweenaw Bay Indian Community and for American Indian and Alaska Natives in general. The increase in high school dropouts for the Saginaw Tribe could be a function of increased job opportunities at the casino or receipt of a full per capita payment.

Comparison of work force data in Table 4 provides a muddled picture as well. The percentage of the population 16 year and older in the labor force is much lower in 2000 for the Saginaw tribe than either of the other Michigan Native groups and is even lower than for American Indian and Alaska Natives overall. Comparable figures are not available for 1990 so we cannot see the change between census years. Data was available to establish the percentage of the population 16 years and older who worked at all in the previous year and who worked 40 
or more weeks in the previous year for both the 1990 and 2000 censuses. The figures for the Saginaw tribe show a decline from 1990 to 2000, 68.3\% to $65.8 \%$, for those "who worked at all in the previous year." The percentages for this category are significantly lower for the Saginaw tribe than either of the other Michigan Native groups, about $80 \%$. The data from the percentage of the population 16 years and older who worked 40 or more weeks in the previous year are interesting. There is a substantial rise in this rate for the Keweenaw Bay Indian Community, $37.1 \%$ to $55 \%$. Given the remoteness of their location in the Upper Peninsula in Michigan it is likely that the opening of the casino provided more year round employment opportunities than the tribal members could find previously. There is only a slight up tick in the figure for the Saginaw Chippewa Tribe, $45.8 \%$ to $47.8 \%$; this is somewhat surprising given the scale of the operation. Again, the receipt of per capita payments may have caused some tribal members to drop out of the labor force while providing others with more stable employment opportunities.

\section{Conclusions}

In answer to the first research question the data lends support to the basic labor theory conclusion that an increase in nonlabor income causes individuals to decrease their work efforts. In answer to the third research question there is weak evidence that the payment of per capita payments from casino profits is increasing the fertility rate of Saginaw Chippewa tribal families. At best, however, this analysis is just a starting point for more detailed research. Better data is necessary to reach firm conclusions on the effect of per capita payments on the behavior of Native Americans. The data does not allow any conclusion on the second research question: Have per capita tribal payments caused a decline in educational attainment by recipients?

\section{References:}

Anders, Gary C., Donald Siegel, \& Munther Yacoub. (1998). "Does Indian Casino Gambling Reduce State Revenues? Evidence from Arizona." Contemporary Economic Policy, 3(16), 347-55. http://dx.doi.org/10.1111/j.1465-7287.1998.tb00524.x

Barlett, Donald L. \& James B. Steele. (2002). "Wheel of Misfortune," Time, December 16. http://dx.doi.org/10.1093/cep/20.4.440

Barron, John M., Michael Staten, \& Stepahnie M. Wilshusen. (2002). “The Impact of Casino Gambling on Personal Bankruptcy Filing Rates." Contemporary Economic Policy, 20(3), 440-55.

Boardman, Barry, \& John J. Perry. (2007). "Access to Gambling and Personal Bankruptcy." Journal of Socio-Economics, 36(5), 789-801. http://dx.doi.org/10.1016/j.socec.2007.01.012

Characteristics of American Indians by Tribe and Language: 1990 Census of Population. Source: U.S. Census Bureau, Population Division, Racial Statistics Branch: (1990) (CP-3-7).

Characteristics of American Indians and Alaska Natives by Tribe and Language: 2000 Census of Population and Housing. Source: U.S. Census Bureau, Population Division, (2000) (PHC-5). 
De la Vina, Lynda \& David Bernstein. (2002). "The Impact of Gambling on Personal Bankruptcy Rates." Journal of Socio-Economics, 31(5), 503-509. http://dx.doi.org/10.1016/S1053-5357(02)00135-X

Elliot, Donald S. \& John C. Navin. (2002) "Has Riverboat Gambling Reduced State Lottery Revenue?" Public Finance Review, 30, 1169-1173. http://dx.doi.org/10.1177/109114210203000304

Evans , William \& Julie Topoleski. (2002). "The Social and Economic Impact of Native American Casinos." NBER Working Paper No. 9198. Cambridge, MA: National Bureau of Economic Research. http://dx.doi.org/10.3386/w9198

Evans, William \& Wooyoung Kim. (2005). "The Impact of Local Labor Market Conditions on the Demand for Education: Evidence from Indian Casinos." Center for Economic Studies, U.S. Census Bureau Working Paper No. 06-14.

Fink, Stephen \& Jonathon Rork. (2003). "The Importance of Self-Selection in Casino Cannibalization of State Lotteries." Economics Bulletin, 10(8), 1-8.

Garrett, Thomas A. \& Mark W. Nichols. (2005). "Do Casinos Export Bankruptcy?" The Federal Reserve Bank of St. Louis Working Paper Series, 2005-019A.

Gazel, Ricardo C., Dan S. Rickman, \& William N. Thompson. (2001). "Casino Gambling and Crime: A Panel Study of Wisconsin Counties." Managerial and Decision Economics, 22, 65-75. http://dx.doi.org/10.1002/mde.998

Grinols, E. L. \& D. B. Mustard. (2006). "Casinos and Crime." Review of Economics and Statistics, 88, 28-45. http://dx.doi.org/10.1162/rest.2006.88.1.28

Indianz.com(http://www.indianz.com/News/2005/010471.asp)

Keweenaw Bay Indian Community (http://www.ojibwa.com/html/gaming.htm)

Michigan Indian Gaming Compacts. Michigan Gaming Control Board. (16 January 2008). http://dx.doi.org/10.1016/j.chemosphere.2007.06.066

National Indian Gaming Commission Homepage. National Indian Gaming Commission. http://www.nigc.gov/

Siegel, Donald \& Gary Anders. (2001). "The Impact of Indian Casinos on State Lotteries: A Case Study of Arizona." Public Finance Review, 2(29), 139-147. http://dx.doi.org/10.1177/109114210102900203

Taylor, Jonathon B. \& Joseph P. Kalt. (2005). "American Indians on Reservations: A Databook of Socioeconomic Change Between the 1990 and 2000 Censuses." The Harvard Project on American Indian Development.

Walker, Douglas M. \& John D. Jackson. (2007). "Do Casinos Cause Economic Growth?" American Journal of Economics and Sociology, 3(66), 593-607. http://dx.doi.org/10.1111/j.1536-7150.2007.00528.x 


\section{Macrothink}

Business and Economic Research

ISSN 2162-4860 2012, Vol. 2, No. 2

Walker, Douglas M. \& John D. Jackson. (1998). "New Goods and Economic Growth: Evidence from Legalized Gambling.” Review of Regional Studies, 28(2), 47-69.

\section{Copyright Disclaimer}

Copyright reserved by the author(s).

This article is an open-access article distributed under the terms and conditions of the Creative Commons Attribution license (http://creativecommons.org/licenses/by/3.0/). 